\title{
Traveler's diarrhea: epidemiology and impact on visitors to Fortaleza, Brazil
}

\author{
Anamaria Cavalcanti, ${ }^{1}$ Sue Ann Costa Clemens, ${ }^{2}$ \\ Frank Von Sonnenburg, ${ }^{3}$ Françoise Collard, ${ }^{4}$ Norbert De Clercq,${ }^{4}$ \\ Robert Steffen, ${ }^{5}$ and Ralf Clemens ${ }^{4}$
}

ABSTRACT Objective. To assess the epidemiology and impact of traveler's diarrhea (TD) among visitors to the city of Fortaleza, Ceará, Brazil, as part of a global study on TD carried out in four countries.

Methods. Within a cross-sectional survey, questionnaires were completed by departing travelers at the Fortaleza airport between March 1997 and February 1998. The questions inquired about demographics, duration of stay, reason for their visit, pretravel health advice they had received, risky food and beverage consumption while in Fortaleza, and quality of life during the visit to Fortaleza in relation to having or not having contracted TD.

Results. A total of 12499 questionnaires were analyzed. The most common reason that the visitors gave for their travel to Fortaleza was a holiday (60.3\%). The total diarrhea attack rate was $13.4 \%$. Younger people (<36 years) had significantly higher TD attack rates than did older persons. Using a logistic regression model, we investigated the visitors' risk factors, including age, gender, length of stay, and trip's purpose. According to that analysis, characteristics that are slightly predictive of TD are gender, length of stay, and visiting as a tourist rather than for some other purpose. Characteristics that protect against contracting TD include being older and traveling for business rather than for some other reason. Of those who were incapacitated by TD, the mean duration of the impairment was 42 hours.

Conclusions. TD affected the travel plans and activities of many of the visitors to Fortaleza. Further, although aware of the health risks, the majority of those travelers did not avoid all potentially contaminated food or beverage items. Given this pattern of behavior, future efforts to combat TD may have to depend on such other alternative strategies as new vaccines.

Key words Diarrhea, travel, health behavior, Brazil.

Travel has been increasing around the world, with, for example, some 35 million people traveling from industrialized countries to tropical or subtropical countries per year, ac- cording to one recent estimate (1). This growth in travel has amplified pressure on local infrastructures that cater to these visitors. In turn, these dramatic changes may have influ-

\footnotetext{
Secretaria de Saúde do Ceará, Fortaleza, Ceará, Brazil. Send correspondence to: Anamaria Cavalcanti, Rua Paulo Moraes, 292 - Papicu, 60155-170 - Fortaleza, CE - Brazil; telephone: 5585 91210641 or 5585 265-1752; fax: 5585 265-1766; e-mail: rcs@baydenet.com.br

2 Instituto de Pós-graduação Médica Carlos Chagas, Rio de Janeiro, RJ, Brazil.
}

\footnotetext{
3 University of Munich, Department of Infectious Diseases and Tropical Medicine, Munich, Germany.

4 GlaxoSmithKline Biologicals, Rixensart, Belgium.

5 University of Zurich, Institute of Social and Preventive Medicine, Division of Epidemiology and Prevention of Communicable Diseases, Zurich, Switzerland.
}

enced the epidemiology of travelrelated illnesses.

Many travelers experience traveler's diarrhea (TD), a self-limited illness that usually resolves spontaneously within a few days but that has the potential for wrecking a meticulously planned business or pleasure trip (2). Among travelers in 1979-1981, TD had an incidence rate of $20 \%-50 \%$ per twoweek stay, depending on the destination (3). More recently, a global survey on TD among travelers, the Traveler 
Diarrhea Survey World Wide (TRADIWOW), was performed among persons visiting popular destinations on three different continents. The four parts of the study were conducted in Brazil (Fortaleza), India (Goa), Jamaica (Montego Bay), and Kenya (Mombasa) $(4,5)$.

The TRADIWOW survey was designed to investigate the epidemiology of TD and the impact on the travelers' well-being as well the etiology of TD, by using stool samples for isolation and analysis of pathogens whenever possible. Since there is also growing evidence indicating that conventional clinical indices of illness correlate weakly with how patients actually feel and how they are able to function in their daily lives, we wanted to assess their retrospective assessment of quality of life during their travel in relation to whether or not they had contracted TD. This type of survey reflects the dimensions of physical, emotional, and social impact of disease and the effect of prophylaxis and/or treatment on the patient. Furthermore, there is a lack of data on the impact of TD in the developing world. Since oral vaccines against enterotoxigenic Escherichia coli (ETEC), rotavirus, and other pathogens may soon be available (6-8), there is a need to determine who might benefit from such vaccines.

This article details the TRADIWOW results obtained in Fortaleza, Brazil. Fortaleza is the capital of the state of Ceará, which is located in the Northeast of Brazil. Fortaleza is one of the leading holiday destinations in Brazil, both for foreign and domestic tourists.

\section{METHODS}

This study was conducted between March 1997 and February 1998. A crosssectional survey of travelers on their way home was carried out at the Fortaleza airport. The information collected was used to analyze TD epidemiology and the subjective and objective impact of TD on the travelers' well-being. Trained interviewers invited departing travelers of both sexes, aged $\geq 16$ years, to fill out a self- administered questionnaire while waiting in the airport departure hall. The questionnaire was provided in six languages-Portuguese, English, French, German, Spanish, and Italian-reflecting the makeup of the tourists using the Fortaleza airport.

The questionnaires were collected by staff before the travelers went to the departure gates. The questionnaires were limited to four pages so they could be completed quickly. Closed questions relating to personal data, type and duration of stay, incidence of diarrhea, and place of stay (hotel, etc., with the major Fortaleza hotels individually listed) were on two pages. On the remaining two pages there were two different sets of questions, "type $\mathrm{A}^{\prime \prime}$ and "type B." The type A questions inquired about pretravel health advice and about such "economic features" as expenses for prophylaxis and for TD therapy and the cost of the stay in Fortaleza. The type B questions investigated food and beverage consumption and quality of life in relation to contracting TD. The questionnaires were distributed during 1 week out of each month for a 12-month period. The type A pages were distributed 6 days out of each week, and the type B ones were distributed on the remaining, randomly selected day of the week.

\section{Quality of life}

The type B questionnaire included demographic and diarrhea-related questions (e.g., type of diarrhea and severity of symptoms) as well as 10 questions specifically assessing various dimensions of quality of life, each of them scored along a seven-point Likert scale. The 10 quality of life questions were adapted from a previously validated instrument assessing quality of life in patients with inflammatory bowel disease $(9,10)$. The maximum score for the best quality of life a traveler could experience during the visit to Fortaleza was 70 (10 questions 37 points per question), while the lowest one was 10 (10 questions 31 point per question). Those travelers not completing all 10 quality of life questions were excluded from this part of the analysis.

\section{Definitions}

As in previous studies (1), classic TD was defined as passage of three or more unformed stools per $24 \mathrm{~h}$, with at least one accompanying symptom (nausea, vomiting, abdominal cramps or pain, fever, or blood in stools). Moderate TD was defined either as passage of one or two unformed stools with at least one accompanying symptom or as more unformed stools without accompanying symptoms. Mild TD was passage of one or two unformed stools without accompanying symptoms. (In this article, the term "TD" or "total TD" is used for the sum of all severity grades.) Severity of accompanying symptoms was graded $1-4$ by the survey respondents. Incapacitation was defined as the inability to pursue planned activities.

Twelve risky food items were to be evaluated; they were: 1) tap water, 2 ) ice cubes, 3) dairy products, 4) ice cream (a dairy product, but asked about separately, to prompt travelers to remember it), 5) rare meat, 6) carne de sol (a local cured-meat specialty), 7) hamburgers, 8) raw oysters, 9) lobster or shrimp, 10) salad, 11) creamy salad dressings, and 12) food purchased from street vendors. If they were consumed occasionally, a score of 1 was attributed per item; if they were consumed daily, a score of 2 was attributed. The maximum possible score was thus 24 .

\section{Statistical analysis}

Data management and tabulations were performed with Epi Info version 6.04b software (Centers for Disease Control and Prevention, Atlanta, Georgia, United States of America). In addition, SAS version 6 software (SAS Institute Inc., Cary, North Carolina, United States) was used for the statistical analysis. The attack rates of diarrhea are presented in this article as proportions, with $95 \%$ confidence 
TABLE 1. Traveler's diarrhea (TD) attack rates (percentages), according to gender and age, Fortaleza, Brazil, 1997-1998

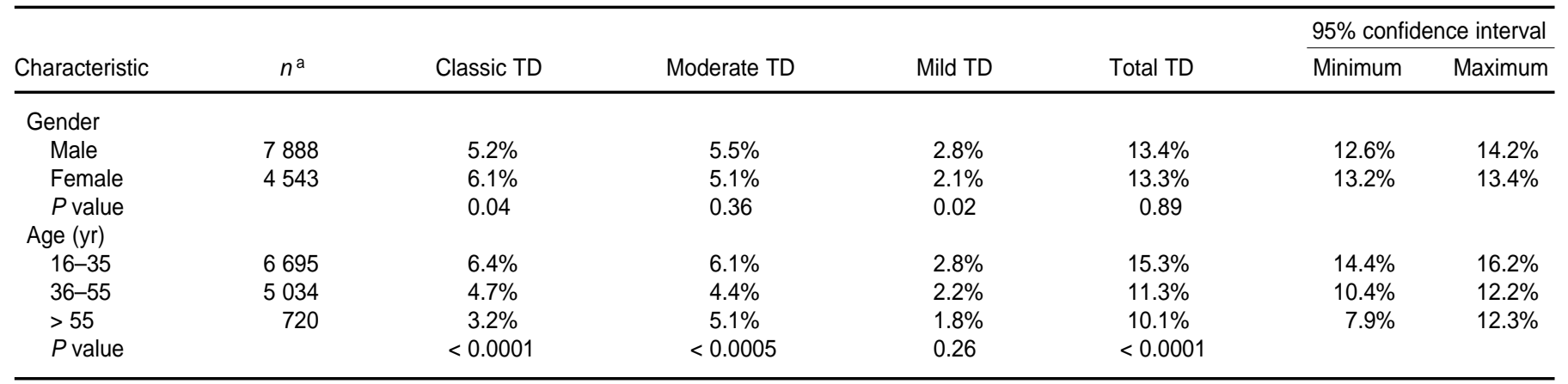

${ }^{a} n=$ number of subjects with available data.

intervals (CIs). Kruskal-Wallis and chi-square tests were applied to compare continuous and discrete predictor variables. The stratified MantelHaenszel method was used to test for confounding variables. Logistic regression was used to study the relationships between the disease in two modalities (diseased or not diseased) and the risk factors, which could be qualitative or quantitative variables.

\section{RESULTS}

At the airport 12893 questionnaires were collected, of which 12449 (96.6\%) could be analyzed according to the protocol inclusion criteria. Of these 12 449 questionnaires, 10843 of them $(87.1 \%)$ were type A and 1606 of them $(12.9 \%)$ were type B. The main demographics for the respondents for the type A questionnaires and for the type B questionnaires were similar.

Overall, $36.5 \%$ of the survey respondents were female, with a mean age of 34.0 years (standard deviation (SD), 11.5 years), and $63.5 \%$ were men, with a mean age of 37.4 years (SD, 10.8 years). The mean duration of stay was 9.8 days (SD, 4.3 days), with a median of 7 days. The primary reasons for visiting Fortaleza were a holiday $(60.3 \%$ of respondents), business $(23.0 \%)$, honeymoon $(3.5 \%)$, and other $(11.1 \%)$; $2.1 \%$ of the persons did not answer this question. Visitors from the South or the Southeast of Brazil accounted for $37.2 \%$ of the study population, $7.7 \%$ came from another Latin American country, $16.6 \%$ were from the United States of America, and 31.8\% came from Europe.

\section{Epidemiology of traveler's diarrhea}

The total TD attack rate over the 12month period was $13.4 \%$ for the total study population: $5.5 \%$ with classical $\mathrm{TD}, 5.3 \%$ with moderate $\mathrm{TD}$, and $2.5 \%$ with mild TD. As shown in Table 1, total TD (any TD) attack rates were significantly higher for younger people $(P<0.0001)$, whereas we did not detect a significant gender-related difference for the total diarrhea attack rate $(P=0.89)$. There was, however, a gender difference for two subcategories, classical TD and mild TD (Table 1). TD attack rates increased significantly $(P<0.0001)$ with duration of stay until day 12 and then remained more or less at a plateau, as is shown in Figure 1.

FIGURE 1. Traveler's diarrhea (TD) attack rates by duration of stay in Fortaleza, Brazil, during 1997-1998




TABLE 2. Traveler's diarrhea (TD) attack rates (\%), according to country of origin or purpose of visit, Fortaleza, Brazil, 1997-1998

\begin{tabular}{|c|c|c|c|c|c|c|c|}
\hline \multirow[b]{2}{*}{ Characteristic } & \multirow[b]{2}{*}{$n$} & \multirow[b]{2}{*}{$\begin{array}{c}\text { Classic TD } \\
(\%)\end{array}$} & \multirow[b]{2}{*}{$\begin{array}{c}\text { Moderate TD } \\
(\%)\end{array}$} & \multirow[b]{2}{*}{$\begin{array}{l}\text { Mild TD } \\
(\%)\end{array}$} & \multirow[b]{2}{*}{$\begin{array}{l}\text { Total TD } \\
(\%)\end{array}$} & \multicolumn{2}{|c|}{$95 \%$ confidence interval } \\
\hline & & & & & & $\begin{array}{l}\text { Minimum } \\
(\%)\end{array}$ & $\begin{array}{l}\text { Maximum } \\
(\%)\end{array}$ \\
\hline South/Southeast of Brazil & 4629 & 4.6 & 5.1 & 2.2 & 11.9 & 11.0 & 12.8 \\
\hline Rest of Brazil & 146 & 6.8 & 4.8 & 2.1 & 13.7 & 8.1 & 19.3 \\
\hline Argentina, Chile, Uruguay & 863 & 5.3 & 4.6 & 3.0 & 13.0 & 10.8 & 15.2 \\
\hline Other Latin American countries & 96 & 2.1 & 6.3 & 5.2 & 13.5 & 6.7 & 20.3 \\
\hline Portugal & 192 & 6.3 & 4.7 & 2.6 & 13.5 & 8.7 & 18.3 \\
\hline Italy & 1733 & 5.6 & 6.1 & 3.6 & 15.3 & 13.6 & 17.0 \\
\hline Spain & 290 & 2.4 & 7.6 & 1.0 & 11.0 & 7.4 & 14.6 \\
\hline Rest of Europe & 1750 & 7.3 & 7.3 & 3.0 & 17.6 & 15.8 & 19.4 \\
\hline Asia & 84 & 9.5 & 2.4 & 2.4 & 14.3 & 6.8 & 21.8 \\
\hline Various other countries & 111 & 12.6 & 6.3 & 1.8 & 20.7 & 13.2 & 28.2 \\
\hline Other & 1377 & 5.5 & 5.9 & 2.0 & 13.4 & 11.6 & 15.2 \\
\hline
\end{tabular}

There was no marked trend in TD attack rates among travelers from different countries or regions (Table 2). People who had stayed in a tropical country within the 6 months prior to travel to Fortaleza did not experience lower TD rates than did people who had not done so. While the diarrhea rates varied over the course of the year of study (Figure 2), we did not find a statistically significant seasonal variation.

FIGURE 2. Seasonal profile of traveler's diarrheal (TD) attack rates in Fortaleza, Brazil, during 1997-1998

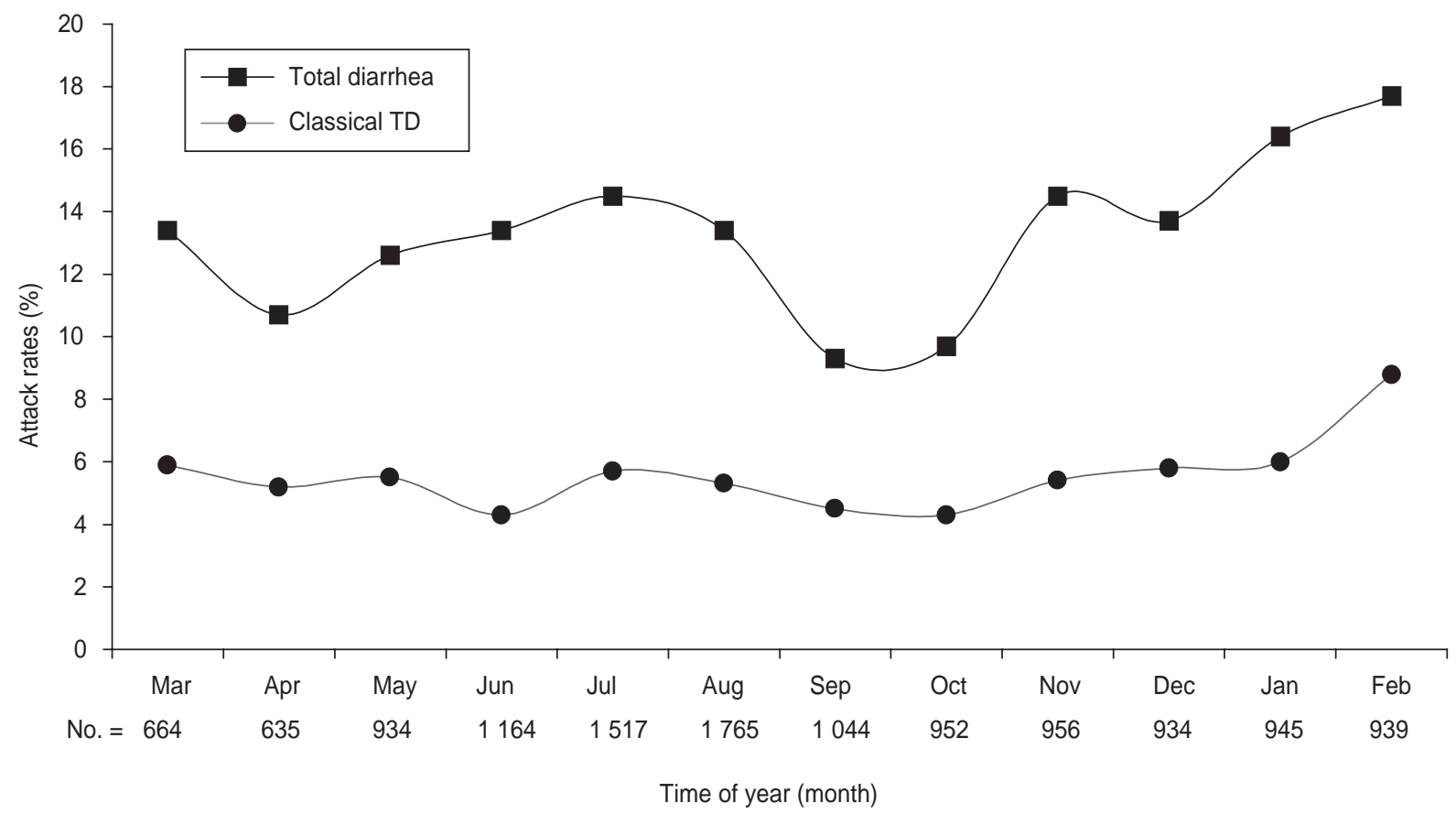


TABLE 3. Chronology and consequence of traveler's diarrhea (TD) in Fortaleza, Brazil, 1997-1998

\begin{tabular}{|c|c|c|c|c|}
\hline & $\begin{array}{l}\text { Classic TD } \\
(n=3243)^{\mathrm{a}}\end{array}$ & $\begin{array}{l}\text { Moderate TD } \\
(n=2824)^{\mathrm{a}}\end{array}$ & $\begin{array}{c}\text { Mild TD } \\
(n=1143)^{a}\end{array}$ & $\begin{array}{l}\text { Any diarrhea } \\
(n=7210)^{\mathrm{a}}\end{array}$ \\
\hline \multicolumn{5}{|l|}{ Chronology } \\
\hline Mean day of onset (median) & $5.7(3.0)$ & $4.9(3.0)$ & $4.3(3.0)$ & $5.1(3.0)$ \\
\hline Mean duration in hours (median) & $80.2(48.0)$ & $54.8(48.0)$ & $40.9(24.0)$ & $62.7(48.0)$ \\
\hline \multicolumn{5}{|l|}{ Consequence } \\
\hline Sought professional help (\%) & $29.3 \%$ & $10.4 \%$ & $4.4 \%$ & $17.1 \%$ \\
\hline Used drug therapy (\%) & $53.0 \%$ & $29.1 \%$ & $27.6 \%$ & $38.7 \%$ \\
\hline
\end{tabular}

a $n$ values are for the number of subjects for whom this criterion could be evaluated.

The median onset of total (any) TD occurred on day 3. The mean for mild diarrhea was day 4 , and for classical diarrhea it was day $5(P=0.048)$ (Table $3)$. The duration of diarrhea was also significantly longer with increasing TD severity $(P<0.005)$, with double the duration for classical TD as compared to mild TD (Table 3). Most people scored severity of the symptoms accompanying their diarrhea as 1 or 2 out of 4. Most people reported having between three and five stools during the worst 24-hour period of their diarrhea (Figure 3). Few people reported more than two accompanying symptoms (Figure 4). In all the categories of diarrhea, having pain or cramps was the most frequent accompanying symptom $(76.3 \%$ for classical TD and $42.4 \%$ for any diarrhea), followed by nausea $(37.7 \%$ for classical TD and $18.9 \%$ for any diarrhea). Incapacitation was reported by 378 of the 1660 TD patients $(22.8 \%)$.

The mean duration of incapacitation for the 378 patients who were impaired through diarrhea was $42.3 \mathrm{~h}$, with a median of $24 \mathrm{~h}$. For those with classic TD, this period was $46.4 \mathrm{~h}$, versus $36.5 \mathrm{~h}$ for those with moderate diarrhea and $17.5 \mathrm{~h}$ for those with mild diarrhea.

For people experiencing any kind of diarrhea, about one in six sought professional help, but this approached one in three for those experiencing classic TD (Table 3), significantly more than for those experiencing moderate or mild diarrhea $(P<0.0001)$. Of the persons seeking professional help, $62 \%$ of them went to a pharmacy and
$25 \%$ went to a doctor for help. In one case, hospitalization was necessary. In the case of classical TD, more than half of the patients took some form of drug therapy, significantly more than for those experiencing mild or moderate diarrhea $(P<0.0001)$ (Table 3$)$. The most used drug was Imodium (loperamide) $(33.1 \%)$, followed by Metifex (ethacritine lactate) (10.2\%).

People who answered that they had only occasionally eaten meals outside their hotel experienced significantly less diarrhea then those who had eaten outside frequently: $4.4 \%$ (95\% confidence interval (CI), 2.3\%-6.5\%) versus $11.7 \%$ (95\% CI, 9.0\%-14.4\%). People who stayed in the major hotels specifically listed on the questionnaire experienced significantly less diarrhea than did people who stayed in nonlisted hotels: $10.5 \%$ (95\% CI, 9.8\%-11.2\%) versus $20.5 \%$ (95\% CI, $18.7 \%-22.3 \%$ ). People who stayed with friends or family had an intermediate diarrhea attack rate, of $16.1 \%$ (95\% CI, $14.7 \%-$ $17.5 \%$ ).

Using a logistic regression model, we investigated the risk factors, such as age, gender, length of stay, and purpose of visit (holiday, business, etc.). Our results showed that the characteristics predictive for contracting TD were male gender (odds ratio $(\mathrm{OR})=1.12,95 \%$ confidence interval (CI) of 1.01-1.26), having a longer stay $(\mathrm{OR}=1.01 ; 95 \% \mathrm{CI}, 1.01-1.02)$, and being a tourist rather than visiting for some other purpose $(\mathrm{OR}=1.36$; 95\% CI, 1.14-1.62). Characteristics that

FIGURE 3. Number of stools for travelers during the worst 24 hours of suffering from traveler's diarrhea (TD) in Fortaleza, Brazil, during 1997-1998

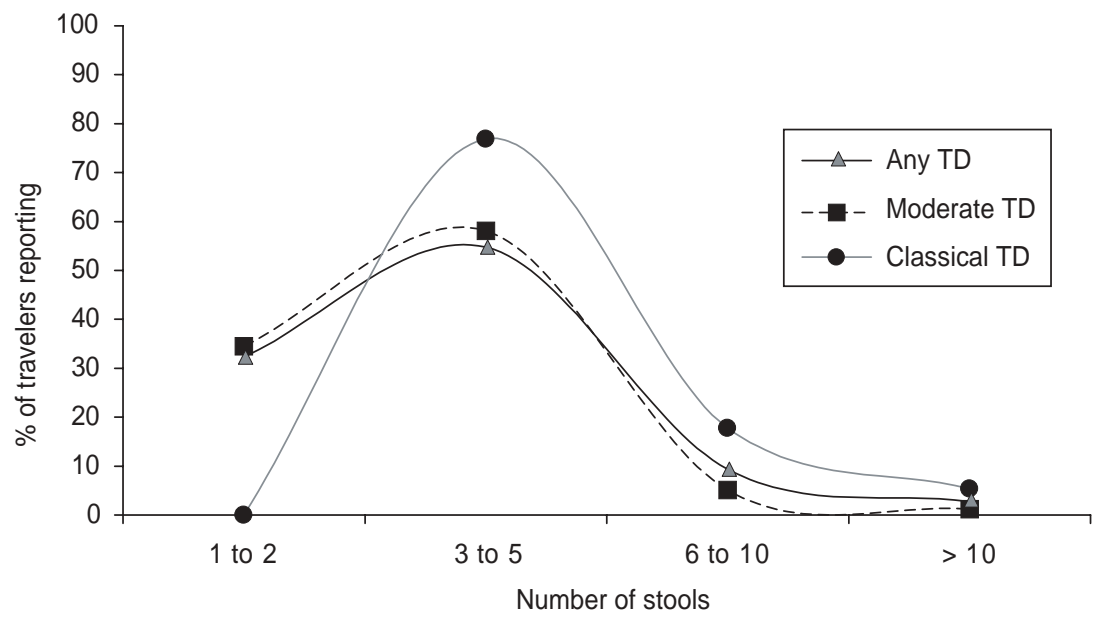


FIGURE 4. Number of accompanying symptoms for travelers suffering from traveler's diarrhea (TD) in Fortaleza, Brazil, during 1997-1998

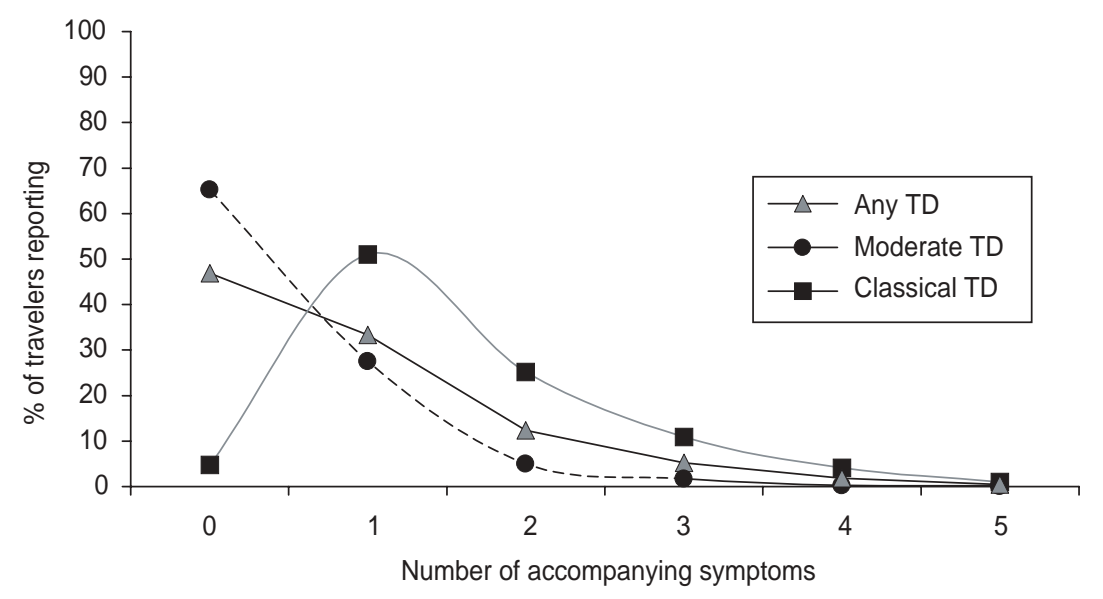

were slightly protective against contracting $\mathrm{TD}$ were being older $(\mathrm{OR}=$ $0.99 ; 95 \%$ CI of $0.98-0.99)$ and traveling for business $(\mathrm{OR}=0.81 ; 95 \% \mathrm{CI}$ of $0.65-0.99)$.

A total of 1606 people answered one or more of the type B questions on risky food and beverage consumption, with response rates varying for the 12 items. Out of 941 persons responding to the question concerning consuming drinks with ice cubes in them, 814 of the persons $(86.5 \%)$ said they had done so at some time during their stay. Out of 928 respondents, 693 of them $(74.7 \%)$ said they had eaten salads; 741 out of $931(79.6 \%)$ ate ice cream; and 781 out of $924(84.5 \%)$ consumed other dairy products. Depending on the specific item, between $48 \%$ and $64 \%$ of the visitors had consumed rare meat, hamburgers, carne de sol, lobster or shrimp, oysters, or creamy dressings. But 767 out of $913(84.0 \%)$ said they never consumed tap water, and 662 out of $912(72.6 \%)$ said they never bought food from street vendors. Those with classical TD scored 9.3 out of a maximum of 24 in the risky food score, as compared to 8.6 among those who did not contract TD (no significant difference, $P=0.36$ ). For mild and moderate TD, there was also no significant differences concerning food items consumed. No single food or beverage item could be identified whose consumption increased the risk of contracting diarrhea.

According to the responses to the type A questions, about half the travelers had asked for health advice either prior to this trip or at some other time in the past. People had most frequently consulted a doctor $(46 \%)$, their travel agent $(18 \%)$, or a travel clinic $(16 \%)$. People who had sought health advice for this trip on what types of food they could safely consume scored significantly lower on the risky food score, 7.0 versus $9.2(P<0.01)$. However, people who had asked for health advice did experience significantly more diarrhea $(17.4 \%$, with $95 \%$ CI of $15.9 .0 \%-$ $18.9 \%)$ than those who did not $(13.5 \%$, with $95 \%$ CI of $12.7 \%-14.3 \%$ ).

\section{Quality of life}

A total of 887 out of the 1606 people who responded to the type $B$ questionnaire pages answered all 10 questions on the quality of life and could thus be included in this part of the analysis. Out of a maximum possible total of 70, the mean score for quality of life was 66.8 for travelers who did not contract TD. This was significantly reduced for others, to 58.9 among persons with any traveler's diarrhea $(P<0.001)$ and to 54.5 for patients suffering from classic TD $(P<0.001)$.

\section{DISCUSSION}

We assessed the epidemiology and impact of traveler's diarrhea (TD) in Fortaleza, Ceará, Brazil, as part of the TRADIWOW global study investigating TD on three different continents. In Jamaica the attack rate of diarrhea was $23.6 \%$ (4), but for India it was $53.9 \%$, and for Kenya it was $54.6 \%$ (5). The incidence rate we measured in Fortaleza, Brazil-13.4\%-was markedly lower than those in the other TRADIWOW study centers as well as in other tropical countries (11).

One might argue that a large portion of the travelers to Fortaleza came from other parts of Brazil and were therefore already somewhat immune. However, we found no significant differences in the TD attack rates for individuals from Brazil and those from other countries and regions. Surprisingly, we found that previous visits to a tropical country did not reduce the chance of being affected by diarrhea, which is contrary to the observation in Jamaica (4). Those who were holiday travelers to Fortaleza had a significantly higher risk of contracting diarrhea than did persons visiting for business reasons, even when adjusted for duration of stay. Overall, there was no gender-related difference in the diarrhea attack rates. However, the logistic regression model indicated that there was a slight, but epidemiologically irrelevant, gender difference, which may be due to other confounding factors. A more detailed analysis showed that males experienced significantly more mild diarrhea and that females experienced more classical TD. The clinical relevance of this observation may be limited, because in another study a gender difference was not found (5).

We found younger people visiting Fortaleza to be at significantly higher risk of contracting TD than were older people. This was independent of duration of stay, as demonstrated by the logistic regression model. A similar result was also found in Jamaica (4) and in older studies (3). This could be related to the greater appetite of younger people and, consequently, 
to ingestion of a higher dose of pathogens. It could also be partially due to more risky behavior by younger people. People staying in the questionnaire-listed major hotels had significantly less diarrhea then those who stayed in smaller, nonlisted hotels, suggesting different standards of hygiene in those two types of hotels.

Lack of dietary discipline designed to avoid "dangerous" foods and beverages has so far mainly been demonstrated for travelers from Europe (12, 13) but was also found in the Jamaican part of the TRADIWOW study, where some three-fourths of the travelers were from either the United States or Canada (4). In Fortaleza, we found that important numbers of people did consume what is considered to be risky food or beverages but that they avoided drinking tap water and buying food from street vendors. Our analysis did not identify any specific food item as being of particularly high risk.

We found that those people who had sought pretravel health advice did experience significantly more diarrhea than those who did not seek such ad- vice, which is an odd finding. An explanation is not obvious, but one can speculate about a tendency for people who were more conscious or anxious about their health to have observed and remembered their bowel movements more precisely. Alternatively, these people seeking pretravel health advice may have felt safer and may therefore have taken more risks while in Fortaleza.

Our study suggests that the less severe forms of diarrhea, described here as moderate and mild TD, could just be milder forms of classic TD. Arguments for this interpretation are the very close timing of the onset of diarrhea and the similar distribution of symptoms. In addition, TD rates related to age and duration of stay were comparable for all three degrees of severity. Nevertheless, moderate and mild TD still result in a considerable impact, as measured by incapacity. The impact of TD is reflected by the effect on the quality of life score, which was significantly reduced by TD. This same feature has been observed in the other TRADIWOW study sites $(4,5)$. Regarding quality of life, we found a direct link with the severity of diarrhea: the more severe the diarrhea experienced while traveling to Fortaleza, the lower the quality of life.

Although not a serious health problem, traveler's diarrhea affects the travel activities of a noticeable number of people (14). If we judge from the proportion of people who had sought health advice before their trip to Fortaleza, individuals seem to be conscious of the health risks associated with traveling to certain destinations. Nevertheless, compliance by these informed travelers was poor, with few of them avoiding all potentially dangerous foods or beverages during their visit. Given that pattern of behavior, future efforts to combat TD may have to focus more on possible vaccines against enteric pathogens.

Acknowledgements. The authors wish to express their gratitude to both the Secretary of Tourism and the Secretary of Health of Ceará and to INFRAERO, the Fortaleza airport authority. The research presented here was sponsored by an unrestricted grant from GlaxoSmithKline Biologicals.

\section{REFERENCES}

1. World Health Organization. The World Health Report 1996. Report of the DirectorGeneral. Geneva: WHO; 1996.

2. DuPont HL, Ericsson CD. Prevention and treatment of traveler's diarrhea. N Engl J Med 1993;328:1821-1827.

3. Steffen R, Van der Linde F, Gyr K, Schär M. Epidemiology of diarrhea in travelers. JAMA 1983;249:1176-1180.

4. Steffen R, Collard F, Tornieporth N, CampbellForrester S, Ashley D, Thompson S, et al. Epidemiology, etiology, and impact of traveler's diarrhea in Jamaica. JAMA 1999;281(9):811-817.

5. von Sonnenburg F, Tornieporth N, Waiyaki $P$, Lowe B, Peruski LF Jr, DuPont HL, et al. Risk and aetiology of diarrhoea at various tourist destinations. Lancet, 2000;356:133-134.

6. Svennerholm A-M, Holmgren J. Oral vaccines against cholera and enterotoxigenic $E$. coli diarrhea. Adv Exp Med Biol 1995;371B:1623-1628.
7. Holmgren J, Svennerholm A-M. New vaccines against bacterial enteric infections. Scand J Infect Dis 1990;Suppl 70:149-156.

8. Jiang Z-D, Mathewson JJ, Ericsson CD, Svennerholm A-M, Pulido C, DuPont HL. Characterization of enterotoxigenic Escherichia coli strains in patients with travelers' diarrhea acquired in Guadalajara, Mexico, 1992-1997. J Inf Dis 2000;181:779-782.

9. Mitchell A, Guyatt G, Singer J, Irvine EJ, Goodacre R, Tompkins C, et al. Quality of life in patients with inflammatory bowel disease. J Clin Gastroenterol 1988;10:306-310.

10. Canadian Coordinating Office for Health Technology Assessment. Guidelines for economic evaluation of pharmaceuticals: Canada. 1st ed. Ottawa: CCOHTA; 1994

11. Peltola H, Gorbach SL. Travelers' diarrhea. Epidemiology and clinical aspects. In: Textbook of travel medicine and health. DuPont HL, Steffen
R, eds. 2nd edition. Hamilton, Ontario, Canada: B.C. Decker Inc.; 2001. p. 78-86.

12. Mattila L, Siitonen A, Kyrönseppä H, Simula I, Peltola H. Risk behavior for travelers' diarrhea among Finnish travelers. J Travel Med $1995 ; 2: 77-84$.

13. Kozicki M, Steffen R, Schär M. 'Boil it, cook it, peel it or forget it': does this rule prevent travellers' diarrhoea? Int J Epidemiol 1985;14(1): 169-172.

14. Black R. Epidemiology of travelers' diarrhea and relative importation of various pathogens. Rev Infect Dis 1990;12(Suppl 1):S73-S79.

Manuscript received 1 May 2001. Revised version accepted for publication on 16 January 2002. 
RESUMEN Objetivo. Evaluar la epidemiología y el impacto de la diarrea del viajero (DV) en personas que visitan Fortaleza, Brasil, como parte de un estudio general sobre la DV efectuado en cuatro países.

La diarrea del viajero: Métodos. Se realizó una encuesta transversal en la que se pidió a personas en el su epidemiología e impacto aeropuerto que salían de Fortaleza entre marzo de 1997 y febrero de 1998 que completaran un cuestionario. Había preguntas sobre sus características demográficas, la duración de su estancia, la razón de la visita, los consejos que habían recibido antes del viaje, el consumo de alimentos y bebidas peligrosas en Fortaleza, y la calidad de vida durante su visita en relación con la presencia o ausencia de DV.

Resultados. Se examinó un total de 12499 cuestionarios. La razón citada con mayor frecuencia para haber viajado a Fortaleza fue tomarse vacaciones $(60,3 \%)$. La tasa de ataque global fue de $13,4 \%$. Las personas más jóvenes ( $<36$ años) tuvieron tasas de ataque mucho más altas que las de edad más avanzada. Usamos un modelo de regresión logística para investigar los factores de riesgo que tenían los turistas, entre ellos la edad, el sexo, la duración de la estancia y el motivo del viaje. Según los resultados de ese análisis, las características que predicen levemente la aparición de DV son el sexo, la duración de la estancia y el estar en viaje de turismo y no de cualquier otro tipo. Ser una persona de mayor edad y haber viajado por razones de negocio en lugar de otros motivos son factores que protegen contra la DV. De las personas que sufrieron discapacitación debido a la DV, la duración media del trastorno fue de 42 horas.

Conclusiones. La VD afectó a los planes y actividades de turismo de muchas de las personas que visitaron Fortaleza. Aunque sabían que corrían un riesgo, la mayoría de esos viajeros no se abstuvieron de consumir alimentos o bebidas que podían estar contaminados. En vista de que así se comportan los viajeros, en un futuro cualquier iniciativa orientada a combatir la DV deberá depender de estrategias de otra índole, como por ejemplo, la aplicación de una nueva vacuna.

\title{
Se aceptan solicitudes para el Programa de Formación en Salud Internacional 2003
}

Se invita a las personas interesadas a concursar por entrar en el Programa de Formación en Salud Internacional de la Organización Panamericana de la Salud (OPS). 日 Programa está dirigido a profesionales residentes de los Estados Miembros de la OPS que tengan 35 años de edad o menos, una Maestría en Salud Pública o su equivalente, y un mínimo de dos años de experiencia en los servicios de salud, en el campo de la educación sanitaria o en la investigación de problemas de salud pública. $日$ programa formativo se desarrolla incorporando a los participantes al trabajo de la Organización en su Sede, en una dinámica de trabajoestudio con una duración de 11 meses.

Todos los concursantes deberán dominar el español o el inglés y saber leer, escribir, hablar y entender el otro idioma. También deberán llenar una solicitud y proporcionar otros documentos que corroboren su experiencia y calificaciones.

日 programa comienza cada año a finales de enero y termina a mediados de diciembre. Los participantes reciben pagos que cubren sus costos de manutención y otros gastos.

La fecha límite para la entrega de solicitudes para el programa de 2003 es el 31 de julio de 2002.

\author{
Información: \\ Programa de Formación en Salud Internacional \\ Programa de Desarrollo de Recursos Humanos \\ División de Desarrollo de Sistemas y Servicios de Salud \\ Organización Panamericana de la Salud (OPS/OMS) \\ 525 Twenty-third St, N.W. \\ Washington, D.C. 20037-2895 \\ Teléfono: (202) 974-3592 \\ Fax: (202) 974-3612 \\ http://www.paho.org/Spanish/HSP/HSR/pfsiacerca.htm
}

